\title{
Peptide-Induced Modulation of Synaptic Transmission and Escape Response in Drosophila Requires Two G-Protein-Coupled Receptors
}

\author{
Markus K. Klose, ${ }^{1,2}$ Jeffrey S. Dason, ${ }^{2}$ Harold L. Atwood, ${ }^{2}$ Gabrielle L. Boulianne, ${ }^{1,3}$ and A. Joffre Mercier ${ }^{4}$ \\ ${ }^{1}$ Program in Developmental and Stem Cell Biology, Hospital for Sick Children, Toronto, Ontario, Canada M5G 1X8, Departments of ${ }^{2}$ Physiology and \\ ${ }^{3}$ Molecular Genetics, University of Toronto, Toronto, Ontario, Canada M5S 1A8, and ${ }^{4}$ Department of Biological Sciences, Brock University, St. Catharines, \\ Ontario, Canada L2S 3A1
}

\begin{abstract}
Neuropeptides are found in both mammals and invertebrates and can modulate neural function through activation of G-protein-coupled receptors (GPCRS). The precise mechanisms by which many of these GPCRs modulate specific signaling cascades to regulate neural function are not well defined. We used Drosophila melanogaster as a model to examine both the cellular and behavioral effects of DPKQDFMRFamide, the most abundant peptide encoded by the dFMRF gene. We show that DPKQDFMRFamide enhanced synaptic transmission through activation of two G-protein-coupled receptors, FmrfReceptor (FR) and Dromyosupressin Receptor-2 (DmsR-2). The peptide increased both the presynaptic $\mathrm{Ca}^{2+}$ response and the quantal content of released transmitter. Peptide-induced modulation of synaptic function could be abrogated by depleting intracellular $\mathrm{Ca}^{2+}$ stores or by interfering with $\mathrm{Ca}^{2+}$ release from the endoplasmic reticulum through disruption of either the ryanodine receptor or the inositol 1,4,5-trisphosphate receptor. The peptide also altered behavior. Exogenous DPKQDFMRFamide enhanced fictive locomotion; this required both the FR and DmsR-2. Likewise, both receptors were required for an escape response to intense light exposure. Thus, coincident detection of a peptide by two GPCRs modulates synaptic function through effects of $\mathrm{Ca}^{2+}$-induced $\mathrm{Ca}^{2+}$ release, and we hypothesize that these mechanisms are involved in behavioral responses to environmental stress.
\end{abstract}

\section{Introduction}

Neuropeptides modulate numerous physiological processes and behaviors by acting as neurotransmitters, neuromodulators, and hormones. Despite their prevalence and broad functions, the precise mechanisms by which-specific peptides influence individual behaviors remain unclear. These mechanisms can be elucidated by determining their actions on-specific neurons, receptors, and intracellular signaling pathways.

FMRFamides are oligopeptides that end in the sequence PheMet-Arg-Phe- $\mathrm{NH}_{2}$ and act as both hormones and neuromodulators; they act on G-protein-coupled receptors (GPCRs) in the central and peripheral nervous systems (Greenberg and Price, 1992; Espinoza et al., 2000; Vilim et al., 2010). In mammals, GPCRs sensitive to FMRFamide peptides regulate muscle contraction, antinociception, feeding behavior, and learning and

\footnotetext{
Received July 12, 2010; revised Aug. 17, 2010; accepted Sept. 6, 2010.

M.K.K. is the recipient of a fellowship award from the Hospital for Sick Children Research Training Center. H.L.A. received grants from Canadian Institutes of Health Research (CIHR) and Natural Sciences and Engineering Research Council of Canada (NSERC). G.L.B. is supported by a grant from CIHR (MOP 14143) and is the recipient of a Tier Canada Research Chair in Molecular and Developmental Neurobiology. A.J.M. is supported by a grant from NSERC. We thank Milton P. Charlton for comments on the manuscript, technical assistance, and provision of resources and David Knight and Maeve Bonner for help with the qPCR.

Correspondence should be addressed to Markus K. Klose, Department of Cellular and Physiological Sciences, University of British Columbia, 2420 Life Sciences Building, 2350 Health Sciences Mall, Vancouver, British Columbia, Canada V6T 1Z4. E-mail:mklose@exchange.ubc.ca.

DOI:10.1523/JNEUROSCI.3612-10.2010

Copyright $\odot 2010$ the authors $\quad 0270-6474 / 10 / 3014724-11 \$ 15.00 / 0$
}

memory (Panula et al., 1996). In Caenorhabditis elegans, hypoxiaenhanced sensory perception is regulated by a circuit that involves the FMRFamide-like neuropeptide FLP-21 and its GPCR, the neuropeptide Y receptor-related protein NPR-1 (Pocock and Hobert, 2010). The npr-1 gene has been associated with a number of different behaviors, including foraging, aggregation, and aerotaxis (de Bono and Bargmann, 1998; Chang et al., 2006; GloriaSoria and Azevedo, 2008). While it is clear that GPCRs play essential roles in regulating a variety of behaviors, the signaling proteins and pathways activated by these receptors remain largely unresolved.

Drosophila has many features that make it an ideal model to study the function of neuropeptides and their cognate receptors. A wide array of molecular genetic tools are available in Drosophila, and its genome has been fully sequenced (Adams et al., 2000). Larval neuromuscular junctions are readily accessible glutamatergic synapses that allow both electrophysiological and optophysiological recordings. Drosophila is also an ideal model for combining behavioral and cellular recording techniques while using both genetic and pharmacological manipulations; thus, this system is ideal for examining the physiological roles of specific signaling molecules in complex pathways.

In Drosophila, FMRFamides are present in neurosecretory cells and have been shown to modulate muscular contractions (Hewes et al., 1998; Kaminski et al., 2002; Eade and Allan, 2009). The Drosophila FMRFamide gene encodes eight neuropeptides, the most abundant of which is DPKQDFMRFamide (Schneider 
et al., 1993). Many Drosophila GPCRs sensitive to peptides structurally related to FMRFamide have been deorphaned using cell culture assays (Cazzamali and Grimmelikhuijzen, 2002; Nichols, 2006), but their in vivo functions have not been investigated and little is known about their downstream effectors in synapses.

Here, we have examined the roles of the ligand DPKQDFMRFamide and two GPCRs in the modulation of synaptic transmission and behavior in Drosophila. We found that the FmrfReceptor (FR) and the Dromyosuppressin Receptor-2 (DmsR-2) are both required for DPKQDFMRFamide-induced enhancement of transmitter release. Optophysiological recordings revealed that the peptide increased the amplitude of $\mathrm{Ca}^{2+}$ signals and that modulation of $\mathrm{Ca}^{2+}$-induced $\mathrm{Ca}^{2+}$ release was required for this effect. We also found a role for both the FR and DmsR-2 in regulating a locomotor response to intense light exposure. Additionally, application of exogenous DPKQDFMRFamide to semiintact larval preparations enhanced fictive locomotion. Thus, DPKQDFMRFamide modulates both synaptic function and behavior through coincident detection mediated by $F R$ and DmsR-2.

\section{Materials and Methods}

Fly stocks. Male and female flies were raised on standard cornmeal medium at $25^{\circ} \mathrm{C}$ and $60-70 \%$ relative humidity, except for larvae used in RNA interference (RNAi) knockdown experiments, which were raised at $29^{\circ} \mathrm{C}$. Early wandering third-instar larvae were selected for the experiments. All stocks were obtained from Bloomington Stock Center (Indiana University, Bloomington, IN).

The Drosophila lines used included Canton-S (CS) and a conditional dominant negative temperature-sensitive dSERCA (Drosophila sarco/ endoplasmic reticulum $\mathrm{Ca}^{2+}$ ATPase) mutant, $\mathrm{CaP} 60 A^{\text {Kum170 }}$, obtained from an ethyl methanesulfonate screen using CS. The CaP60A ${ }^{\text {Kum } 170} \mathrm{mu}-$ tants, which fail to pump calcium back into the endoplasmic reticulum (ER) at high temperatures, were used to deplete calcium stores in the ER. Calcium ATPase function on the endoplasmic reticulum can be disrupted in these mutants by incubating them in $\mathrm{Ca}^{2+}$-free $\mathrm{HL} 3$ at $40^{\circ} \mathrm{C}$ for $8 \mathrm{~min}$, preventing the refilling of the calcium stores (Sanyal et al., 2005). Two inositol 1,4,5trisphosphate $\left(\mathrm{IP}_{3}\right)$ receptor mutants were used, $P\{E P g y 2\} I t p-r 83 A^{E Y 02522}$ and $P\{P Z\} I t p-r 83 A^{05616}$ ry506. These two lines were kept balanced over TM3green fluorescent protein (GFP) and crossed into a $w^{1118}$ background for testing. The ryanodine receptor mutant $P\{l a c W\} R y a-r 44 F^{k 04913}$ was kept balanced over CyO-GFP and was crossed into a $w^{1118}$ background for testing. We also used mutants for the three G-protein-coupled receptors, $M i\{E T 1\} F R^{M B 04659}$, Mi $\{E T 1\} D m s R-2^{M B 05984}$, and P\{EPgy2 $\} D m s R-1^{E Y 03017}$. UAS regulatory sequences were used to drive the expression of inverted repeats to interfere with both the Fmrf Receptor ( $y^{l} v^{1} ; P\{$ TRiP.JF01879\}attP2) and the Dromyosuppressin Receptor ( $y^{l} v^{I}$; P\{TRiP.JF01850 $\left.\} a t t P 2\right)$ using either a muscle-specific (24b-GAL4) or neuron-specific driver (elav-GAL4).

Real-time reverse transcription PCR. To examine transcript levels of $\mathrm{IP}_{3}$ and NMDA receptors, we used real-time PCR. RNA was extracted from $w-; P\{P Z\} I t p-r 83 A^{05616} r y 506 /+, w-; P\{E P g y 2\} I t p-r 83 A^{E Y 02522} /+$, and $w^{1118}$ flies using TRIzol (Invitrogen). RNA was treated with amplification grade DNase1 (Invitrogen) and then reverse transcribed using the SuperScript II kit (Roche). cDNA was amplified using Roche Light Cycler 480 real-time PCR and SYBR Green-1 reagents. Copy number alterations were assessed by relative quantification methods that compensate for differences in target and reference amplification efficiencies. Expression levels of the rp49 transcript were used as an internal control among genotypes, and relative mRNA levels were calculated using the comparative $\Delta \mathrm{Ct}$ (cycle threshold) method. The P\{PZ\}Itp-r83A$A^{05616}$ insertion maps within both the Itp-r83A and Nmdarl genes, while the $P\{E P g y 2\} I t p-r 83 A^{E Y 02522}$ maps 17 base pairs from the $5^{\prime}$ end of Nmdar 1 (supplemental Fig. 1, available at www.jneurosci.org as supplemental material). Thus, reverse transcription PCR was performed to assess mRNA levels of both the $\mathrm{IP}_{3}$ and the NMDA receptor in each of the P-element insertion lines. Transcript levels of Itp-r83A in $w-$; $P\{E P g y 2\} I t p-r 83 A^{E Y 02522} /+$ were $0.49 \pm 0.04$ relative to $w^{1118}$; similarly, $w-; P\{P Z\}$ Itp-r83A ${ }^{05616} r y 506 /+$ levels were $0.53 \pm 0.04$, relative to controls. Nmdarl-RA transcript levels in $w-; P\{E P g y 2\} I t p-r 83 A^{E Y 02522} /+$ were $0.81 \pm 0.21$ relative to controls, which was not a significant reduction, while in $w^{-;} ;\left\{\{P Z\}\right.$ Itp- $r 83 A^{05616} r y 506 /+$, levels were significantly reduced to $0.52 \pm 0.1$ of controls. Thus, $P\{$ EPgy 2$\} I t p-r 83 A^{E Y 02522}$ showed no significant decrease in NMDA transcript, but it was significantly decreased in $P\{P Z\}$ Itp-r83A 05616 .

The following primers were used: $\mathrm{IP}_{3}$ receptor, $5^{\prime}$-GCTGCTCATTAAGAACCTGT-3' (forward) and 5'-GGTATTGAACGATTCTTGGA-3' (reverse); NMDA receptor, 5'-GGAGCTCTCCAACATGTATC-3' (forward) and $5^{\prime}$-GAGATGAATCCCAGATGAAG-3' (reverse); RP49, 5'-AGTGCGTCGCCGCTTCAAGG-3P (forward) and 5' -AGAACGCAGGCGACCGTTGG-3' (reverse).

Locomotion assay. We developed a behavioral stress response assay that mimics conditions of direct sun exposure on larvae. The larvae were placed on the inside lid of a plastic dish that had moistened tissue paper covering it. Larvae were first observed for 2 min under minimal light conditions at room temperature. Then, a bright, full spectrum light was shone directly onto the larvae through the plastic dish. The distance between the light and the larvae was kept constant. The temperature was measured between 34 and $36^{\circ} \mathrm{C}$. Wandering paths were digitized and measured using ImageJ (National Institutes of Health; rsb.info.nih.gov/ij/).

Fictive locomotion assay. Intact larvae were restrained on a Sylgard dish with dissecting pins bent to resemble horseshoes. The number of peristaltic waves were counted over a $2 \mathrm{~min}$ period and used as a measure of locomotor activity. Semi-intact larvae were dissected up the midline to allow replacement of the hemolymph with the hemolymph-like saline HL3 (Stewart et al., 1994). HL3 contained the following (in mM): $\mathrm{CaCl}_{2}$ (1.25 mM), $\mathrm{MgCl}_{2}$ (20.0), $\mathrm{KCl}(5.0), \mathrm{NaCl}(70), \mathrm{NaHCO}_{3}(10.0), \mathrm{N}, \mathrm{N}-$ bis(2-hydroxyethyl)-2-aminoethanesulfonic acid (5.0), trehalose $2 \mathrm{H}_{2} \mathrm{O}$ (5.0), sucrose (115.0). The nervous system and body wall muscles remained intact. In some experiments DPKQDFMRFamide $\left(5 \times 10^{-6} \mathrm{M}\right)$ was added to the saline.

Physiological procedures. For physiological experiments, the dissection was performed in Schneider's Insect Medium (Sigma-Aldrich) to prevent contractions and minimize the chance of damaging the preparation during the dissection. The larva was cut up the dorsal midline, pinned open, and cleaned of its internal organs, leaving the nervous system and body wall muscles intact. Physiological recordings were obtained from preparations that were continually superfused with HL3 solution. During the imaging of evoked $\mathrm{Ca}^{2+}$ responses, $7 \mathrm{~mm}$ L-glutamate was added to the solution to desensitize glutamate receptors and prevent muscle contractions (Macleod et al. 2002). In both electrophysiological and calcium imaging experiments, the distal cut ends of the nerves were sucked into a glass stimulating electrode and stimulated at $2 \mathrm{~Hz}$ with a Grass S48 stimulator or the A-M Systems isolated pulse stimulator model 2100 using impulses having a duration of $0.2-0.5$ milliseconds and suprathreshold stimulus intensity $(4-6 \mathrm{~V})$.

Intracellular recordings were simultaneously recorded from muscles 6 and 13 using glass microelectrodes filled with $1 \mathrm{M} \mathrm{KCl}$, with a tip resistance of $\sim 40 \mathrm{M} \Omega$. Stimulus intensity was constantly monitored to ensure recruitment of only type $1 \mathrm{~b}$ nerve terminals. Extracellular focal recordings were made from single $1 \mathrm{~b}$ boutons of the motor neuron MN6/7-1b (Hoang and Chiba, 2001). Focal macropatch electrodes with tips having an inner diameter of $5 \mu \mathrm{m}$ were used to enclose single $1 \mathrm{~b}$ boutons that were identified using a $40 \times$ water-immersion lens and Nomarski optics. Quantal content (mean number of quanta released per impulse) was calculated for individual boutons by measuring the amplitude of their stimulus-evoked excitatory junction currents (EJCs) and dividing that by the mean amplitude of their spontaneous miniature excitatory junction currents (mEJCs) (Dason et al., 2009).

Calcium measurements. Calcium kinetics were examined at high temporal resolution using the calcium-sensitive fluorescent indicator Oregon Green 488 (1,2-bis (o-aminophenoxy)ethane- $N, N, N^{\prime} N^{\prime}$-tetraacetic acid (BAPTA)-dextran (OGB). The indicator was loaded into the cut end of the motor axon, a procedure that does not alter calcium regulation (Macleod et. al, 2002; Klose et al., 2008). Line scanning through individual type $1 \mathrm{~b}$ nerve terminals was done using a Bio-Rad 600 confocal scan head (Bio-Rad MRC-600 software) on a Nikon upright microscope 
(Optiphot-2) with a $40 \times$ Olympus water immersion objective [0.7 numerical aperture (NA)]. Images were acquired using a BHS filter set [exciter filter, $488 \mathrm{~nm}$ DF10; emission filter, OG $515 \mathrm{~nm}$ low pass (LP); dichroic reflector, $510 \mathrm{~nm} \mathrm{LP]}$. Fluorescence $(F)$ is reported in arbitrary units with background subtracted. Nerves were stimulated at $2 \mathrm{~Hz}$ in 2.0 mM external calcium concentration unless stated otherwise.

Measurements of $\mathrm{Ca}^{2+}$ concentration in type $1 \mathrm{~b}$ nerve terminals were obtained using the calcium indicator Fura-dextran (10 kDa; Invitrogen). Type $1 \mathrm{~b}$ nerve terminals have a larger volume than their type $1 \mathrm{~s}$ counterparts and evoke smaller initial postsynaptic responses. During highfrequency stimulation the $1 \mathrm{~b}$ terminals facilitate while $1 \mathrm{~s}$ terminals depress (Lnenicka and Keshishian, 2000). Fluorescence from the nerve terminals of Fura-dextran-loaded neurons was detected with an intensified charge-coupled device camera (PTI, model IC-100) connected to a Lightning 2000 frame grabber controlled by Axon Imaging Workbench 2.2 (AIW 2.2) (both from Molecular Devices). Emitted light was collected by an Olympus water immersion objective $(40 \times, 0.7 \mathrm{NA})$ through a $530 \pm 35 \mathrm{~nm}$ bandpass filter, both mounted on an upright Nikon (Optiphot-2) microscope. The loaded neurons were excited with light from a mercury arc lamp alternately through $340 \pm 5$ and $380 \pm 5 \mathrm{~nm}$ bandpass filters on a rapidly switching filter wheel (Omega Optical). Measurements of fluorescence in response to excitation at these two wavelengths allow ratiometric calculation of intraterminal $\left[\mathrm{Ca}^{2+}\right]$. In the experiments which used Fura-dextran, images were taken for 200 milliseconds, once every $5 \mathrm{~s}$, throughout a $15 \mathrm{~s}$ period at rest.

The value for the dissociation constant $\left(K_{\mathrm{d}}\right)$ was taken as $865 \mathrm{nM}$ following previous work by Macleod et al. (2002) and Bronk et al. (2005). Briefly, the maximum $\left(R_{\max }\right)$ and minimum $\left(R_{\min }\right)$ fluorescence values for the preparation in the experimental chamber are obtained and used to calculate the $K_{\mathrm{d}}$ of the indicator (Grynkiewicz et al. 1985). For further details on calibration of the indicator see Klose et al. (2008).

ImageJ software (http://rsb.info.nih.gov/ij/) was used to convert PIC image files to TIFF format, allowing measurement of average pixel value within selected image regions or within lines of a line scan image. A region not containing any calcium indicator fluorescence or autofluorescence was randomly selected beside each fluorescent nerve terminal, and the average pixel intensity was measured in this region to give a background value. This value was subtracted numerically from the average pixel value of a region or line containing the fluorescent element of interest to generate the value $F . \Delta F / F$ is defined as the change in $F$ during stimulation, normalized to $F$ before nerve stimulation. The amplitudes of the calcium responses were measured from baseline to peak and averaged for each nerve terminal over four consecutive pulses $0.5 \mathrm{~s}$ apart. Two to four boutons were tested in each preparation. Only boutons with initial response amplitudes $>0.125$ arbitrary units in $2 \mathrm{~mm}$ extracellular calcium were used for further testing. Each data point represents averaged values from one preparation.

Depletion of ER calcium stores. Depletion of ER calcium stores was performed in $\mathrm{CaP} 60 \mathrm{~A}^{\mathrm{Kum} 170}$ mutants following the OGB loading procedure. Larval CaP60A ${ }^{\text {Kuml7o }}$ preparations were heat shocked to inactivate their temperature-sensitive sarco/endoplasmic reticulum $\mathrm{Ca}^{2+}$ (SERCA) pumps to prevent reuptake of calcium into the ER. Heat shock was administered by placing the preparation in a sealed Petri dish with moist paper; the dish was then placed for $8 \mathrm{~min}$ in an oven set at $40^{\circ} \mathrm{C}$. ER $\mathrm{Ca}^{2+}$ was depleted by stimulating the nerve for $4 \mathrm{~min}$ at $30 \mathrm{~Hz}$ following the temperature-induced inactivation of SERCA.

Pharmacology. DPKQDFMRFamide at $5.0 \times 10^{-7} \mathrm{mM}$ was used in each of the experiments. The combination of DPKQDFMRFamide and L-glutamate $(7 \mathrm{~mm})$ caused an increase in muscle tonus and twitching in the muscle (Clark et al., 2008) that made fluorescence imaging unreliable. The spontaneous muscle twitching was blocked by $10 \mu \mathrm{M}$ nifedipine. Xestospongin B (100 nM) was used to block release of calcium from $\mathrm{IP}_{3}$ receptors, while $100 \mu \mathrm{M}$ ryanodine was used to block the release of calcium from the ryanodine receptor. KN-93 $(1 \mu \mathrm{M})$ was used to disrupt calmodulin-dependent protein kinase II (CaMKII), while the same concentration of the inactive analog $\mathrm{KN}-92$ was used as a control.

Statistical analysis. Significance of $p<0.01$ (unless stated otherwise) was assessed with a $t$ test or two-way ANOVA with the appropriate post hoc test (Tukey) where applicable. All values are reported as mean \pm
SEM. Time constants of signal decay were determined with nonlinear regression analysis using the equation $y=a e^{-b x}$ (Sigmaplot 11 software). Only the single exponential component was used in the analysis.

\section{Results}

\section{Modulation of transmitter release}

We examined the synaptic effects of DPKQDFMRFamide at the well characterized larval body wall neuromuscular junction using a combination of electrophysiological and optophysiological recording techniques. Excitatory junction potentials (EJPs) evoked from type $1 \mathrm{~b}$ nerve terminals (Fig. $1 \mathrm{~A}$ ) increased in amplitude by $22.9 \pm 6.1 \%$ within 5 min of application of the peptide (Fig. $1 B-D)$. In addition, we found that the effect on EJP amplitude persisted for many minutes after washing the peptide out of the bath (Fig. $1 D$ ). We also recorded synaptic currents directly from type $1 \mathrm{~b}$ nerve terminals using extracellular recording electrodes before and after peptide application (Fig. $2 A, B$ ). The quantal content in CS larvae was $4.5 \pm 0.3$ before the addition of peptide and increased significantly to $6.1 \pm 0.6$ following its application (Fig. 2C, Table 1). EJC amplitude in CS preparations increased significantly following peptide application, whereas there was no effect on the amplitude of spontaneously released mEJCs (Fig. 2Cii,Ciii). We tested for DPKQDFMRFamide-induced synaptic effects in mutants of the FR and DmsR-2 receptors to determine what role the two receptors play in the observed synaptic effects. No significant change in quantal content, EJC amplitude, or mEJC amplitude was observed in either $F R^{M B 04659}$ or DmsR$2^{M B 05984}$ larvae following DPKQDFMRFamide application (Fig. $2 C$, Table 1). The frequency of mEJCs was not altered by the peptide in any synapses (Table 1). Thus, both the FR and the $D m s R-2$ are necessary for DPKQDFMRFamide-induced enhancement of quantal content.

\section{Modulation of presynaptic calcium regulation}

Quantal content can be modulated by altering cytosolic calcium levels or by altering sensitivity to calcium (Zucker, 1996; de Jong and Verhage, 2009). Thus, we examined the effects of DPKQDFMRFamide on presynaptic $\mathrm{Ca}^{2+}$ regulation by recording fluorescence from individual type $1 \mathrm{~b}$ boutons loaded with the calcium-sensitive Oregon Green 488 BAPTA-dextran. These nerve terminals were scanned every $4 \mathrm{~ms}$ during $2 \mathrm{~Hz}$ stimulation. Presynaptic calcium responses (transients) resulting from single stimuli applied to the nerve were recorded in nerve terminals using the calcium-sensitive calcium fluorophore Oregon Green BAPTA-488 (Fig. 3A, red arrow). Increasing the extracellular calcium concentration $\left(\left[\mathrm{Ca}^{2+}\right]_{\mathrm{e}}\right)$ significantly increased the amplitude of calcium transients but did not alter the time constant of decay (Fig. 3B), indicating that the level of $\mathrm{Ca}^{2+}$ entering the nerve terminal under these conditions does not affect the nerve terminal's ability to clear free $\mathrm{Ca}^{2+}$ from the cytosol (Tank et al., 1995). Application of DPKQDFMRFamide ( $0.5 \mu \mathrm{M})$ to the physiological recording solution caused an increase in muscle tonus and spontaneous muscle twitching that made recording of calcium transients difficult. To prevent this disruptive effect, nifedipine $(10 \mu \mathrm{M})$ was added to the physiological solution to block the postsynaptic effects of the peptide in the recording solution (Clark et al., 2008). Nifedipine, which blocks L-type calcium channels, did not alter the evoked $\mathrm{Ca}^{2+}$ responses recorded in the presynaptic terminals (Fig. $3 B$ ). DPKQDFMRFamide reversibly increased the amplitude of evoked $\mathrm{Ca}^{2+}$ responses in presynaptic terminals without affecting time constant of decay (Fig. 3C). At $1.25 \mathrm{~mm}$ extracellular $\mathrm{Ca}^{2+}$, the amplitude of the normalized evoked response was $0.142 \pm 0.010$, and after peptide application 

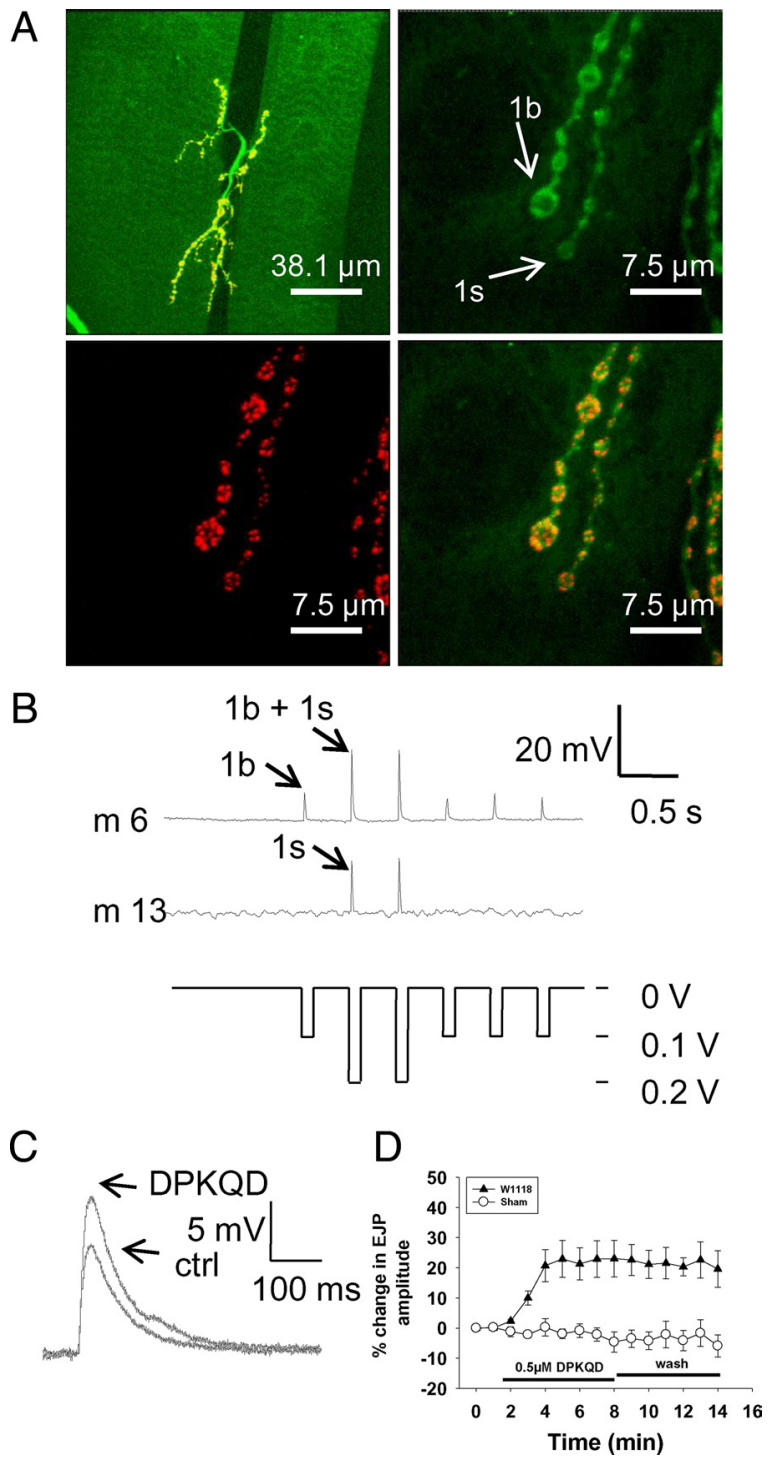

Figure 1. EJP modulation by DPKQDFMRFamide. A, Neuromuscular junctions and synapses of larval Drosophila. At the top left is a low-power view of the neuromuscular junctions on abdominal muscles 6 and 7 formed by two motor axons that supply type $1 \mathrm{~b}$ and $1 \mathrm{~s}$ innervation. The boutons are stained with anti-horseradish peroxidase antibody (top right, green) and antibody nc82 against the active zone structural protein Bruchpilot (bottom left, red) to illustrate multiple synapses on each bouton; the merged image is also shown (bottom right). $\boldsymbol{B}$, Excitatory junctional potentials recorded intracellularly from abdominal muscles 6 and 13 . A stimulus intensity of $0.1 \mathrm{~V}$ initially recruits the MN6/7-1b (RP3) axon, which innervates only muscle 6 and 7 with tonic-like type $1 \mathrm{~b}$ nerve terminals. Increase in stimulus intensity to $0.2 \mathrm{~V}$ additionally recruits the MNSNb/d-1s axon, which innervates muscles 6, 7, 12, and 13 with phasic-like type 1 s terminals. Muscle 13 was therefore used as a monitor to detect accidental recruitment of type 1s terminals during the experiment. C, Application of $0.5 \mu \mathrm{m}$ DPKQDFMRFamide increased the amplitude of EJPs recorded in muscle 6 with stimulation of only type $1 \mathrm{~b}$ terminals. ctrl, Control. $D$, Application of $0.5 \mu \mathrm{m}$ DPKQDFMRFamide induced an increase in amplitude of $\sim 20 \%$ and did not significantly change following washout (wash) of the peptide $(n=6 ; p=0.7)$. "Sham" indicates application of hemolymph-like solution containing no peptide.

it increased significantly to $0.169 \pm 0.008$ (Fig. 3Ci). Washout of the peptide restored the amplitude to $0.143 \pm 0.009$ within $4 \mathrm{~min}$, which was significantly less than with the peptide and not different than before peptide application (Fig. 3Ci). In $2.0 \mathrm{~mm}$ extracellular $\mathrm{Ca}^{2+}$, the normalized amplitude of the evoked response was $0.176 \pm 0.012$; this increased significantly with peptide application to $0.206 \pm 0.013$ and reversed with washout of the peptide (Fig. 3Cii). Decay time constant was not altered by the
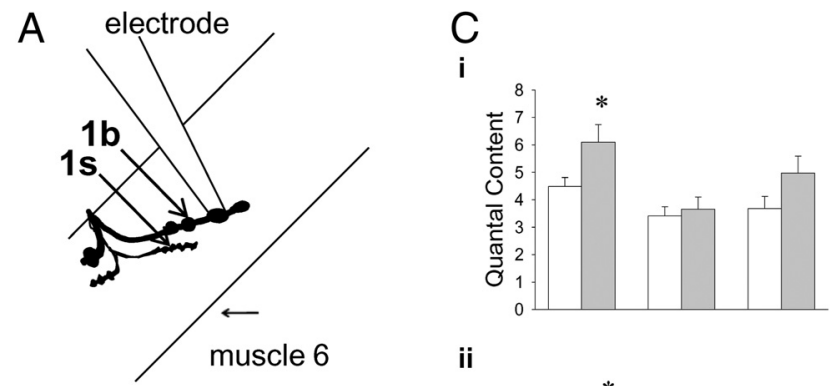

B

pre FMRFamide FMRFamide
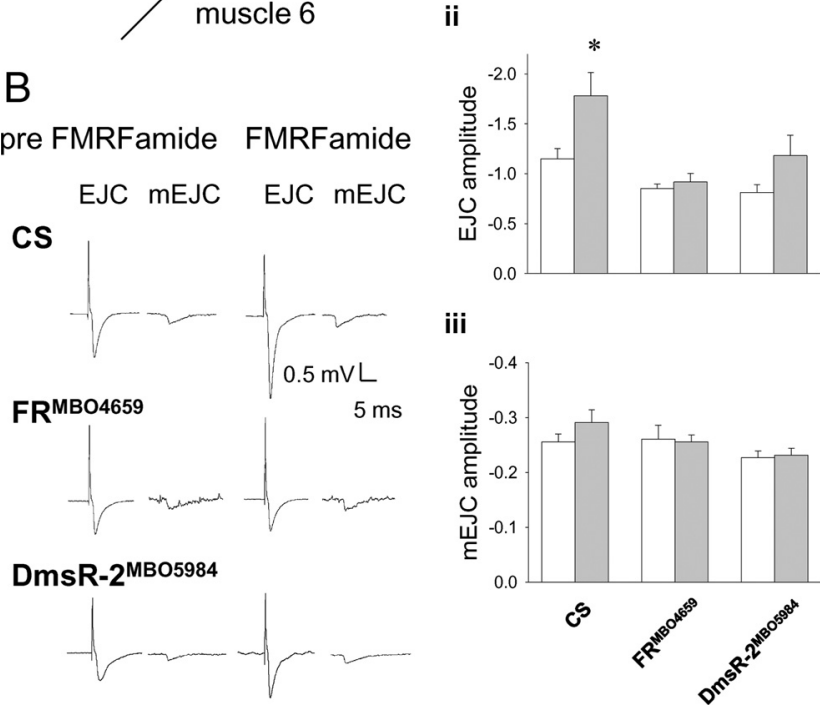

iii

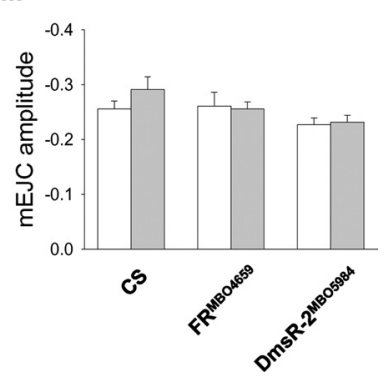

Figure 2. Modulation of excitatory junctional current recordings from type $1 \mathrm{~b}$ boutons disrupted in FR but not DmsR-2 receptor mutants. $A$, Schematic of experimental set-up used to record quantal synapticcurrents from type $1 \mathrm{~b}$ nerveterminals on muscle 6 of the Drosophila abdominal wall. $B$, Traces of evoked EJCs and mEJCs before and after application of peptide. Ci, Quantal content in CS preparations $(n=6)$ increased significantly following peptide application from $4.5 \pm 0.3$ to $6.1 \pm 0.6$ (two-way ANOVA, $p>0.05$ ), but there was no significant effect of peptide application in either $\mathrm{FR}^{\mathrm{MB0} 4659}(n=6 ; p=0.7)$ or DmsR ${ }^{\mathrm{MB05984}}(n=8 ; p=0.06)$ preparations. Cii, The amplitude of ECs in CS preparations $(n=6)$ increased significantly from $-1.15 \mathrm{mV} \pm 0.1 \mathrm{mV}$ to $-1.8 \pm 0.2 \mathrm{mV}$ following peptide application (two-way ANOVA, $p>0.05$ ), but the peptide had no significant effect in $\mathrm{FR}^{\mathrm{MBO} 0459}(n=6 ; p=0.7)$ or DmsR ${ }^{\mathrm{MBO} 05984}$ ( $n=8 ; p=0.06$ ) preparations. Ciii, The amplitude of spontaneously released $\mathrm{mE} C \mathrm{~S}$, measures of postsynaptic sensitivity, did not significantly change following peptide application in $C S(n=6), \mathrm{FR}^{\mathrm{MB04659}}(n=6)$, or DmsR ${ }^{\mathrm{MB05984}}(n=8)$ preparations (two-way ANOVA, $p=0.4$ ). White bars are before the peptide was added and grey bars are following DPKQDFMRFamide application. Asterisks $(*)$ indicate significant difference.

Table 1. Effect of DPKQDFMRFamide on parameters of quantal synaptic recordings

\begin{tabular}{|c|c|c|c|c|c|c|c|c|}
\hline & \multicolumn{2}{|c|}{ Quantal content } & \multicolumn{2}{|c|}{$\begin{array}{l}\text { EJC amplitude } \\
\text { (mV) }\end{array}$} & \multicolumn{2}{|c|}{$\begin{array}{l}\text { mEJC amplitude } \\
\text { (mV) }\end{array}$} & \multicolumn{2}{|c|}{$\begin{array}{l}\text { mEJC frequency } \\
(\mathrm{Hz})\end{array}$} \\
\hline & Pre & FMRF & Pre & FMRF & Pre & FMRF & Pre & FMRF \\
\hline \multicolumn{9}{|l|}{ CS } \\
\hline Average & 4.49 & $6.10^{*}$ & -1.15 & $-1.78^{*}$ & -0.26 & -0.29 & 0.032 & 0.026 \\
\hline SEM & \pm 0.32 & \pm 0.64 & \pm 0.11 & \pm 0.23 & \pm 0.01 & \pm 0.02 & \pm 0.007 & \pm 0.007 \\
\hline \multicolumn{9}{|l|}{ FR } \\
\hline Average & 3.41 & 3.66 & -0.85 & -0.92 & -0.26 & -0.26 & 0.009 & 0.014 \\
\hline SEM & \pm 0.30 & \pm 0.40 & \pm 0.04 & \pm 0.08 & \pm 0.02 & \pm 0.01 & \pm 0.004 & \pm 0.003 \\
\hline \multicolumn{9}{|l|}{ DmsR-2 } \\
\hline Average & 3.68 & 4.97 & -0.81 & -1.18 & -0.23 & -0.23 & 0.014 & 0.016 \\
\hline SEM & \pm 0.44 & \pm 0.63 & \pm 0.08 & \pm 0.20 & \pm 0.01 & \pm 0.01 & \pm 0.003 & \pm 0.004 \\
\hline
\end{tabular}

The averages and SEM quantal content, EJC amplitude, $\mathrm{mEJC}$ amplitude, and $\mathrm{mEJC}$ frequency are shown for wildtype CS as well as for FR and DmsR-2 mutants. Both quantal content and EJC amplitude in CS larvae was increased following peptide application; however, there were no significant effects on either receptor mutant. There were no significant effects of the peptide on $\mathrm{mEJC}$ amplitude or mEJC frequency in any lines. Bold numbers with an asterisk reveal a statistically significant increase resulting from peptide application. Pre, Pre-DPKQDFMRFamide.

peptide at 1.25 or $2.0 \mathrm{~mm}\left[\mathrm{Ca}^{2+}\right]_{\mathrm{e}}$ (Fig. 3Ciii,Civ). The time constant of decay in terminals bathed in $2.0 \mathrm{~mm}\left[\mathrm{Ca}^{2+}\right]_{\mathrm{e}}$ was $42.6 \pm$ $8.0 \mathrm{~ms}$ in controls and $39.7 \pm 10.4 \mathrm{~ms}$ following peptide application, revealing no significant change (Fig. 3Cii). 

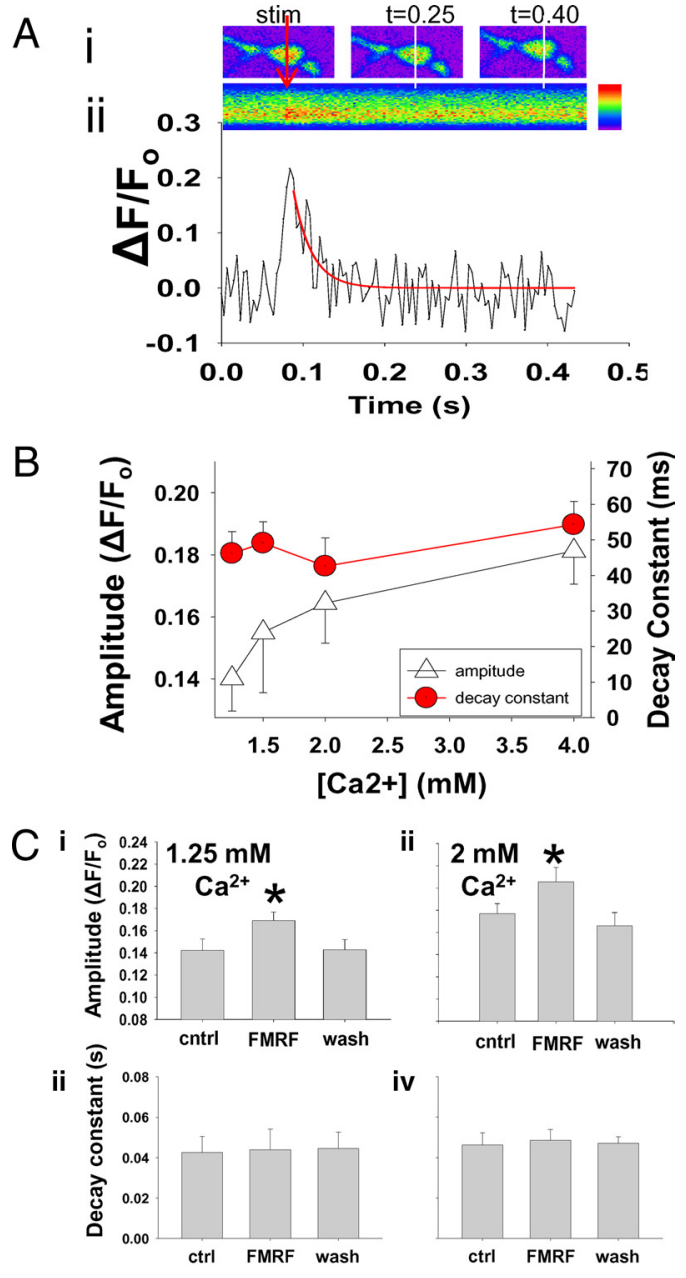

iv
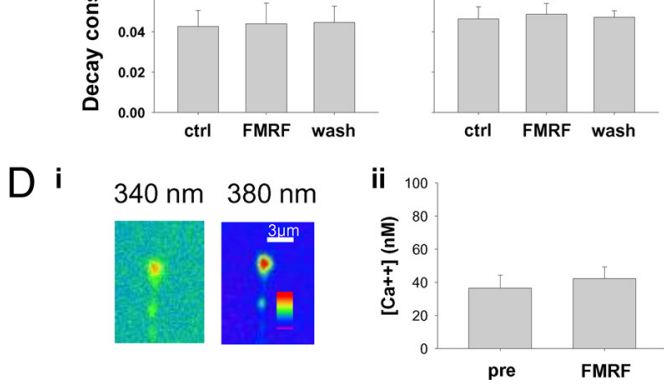

Figure 3. DPKQDFMRFamide reversibly increases amplitude of evoked $\mathrm{Ca}^{2+}$ responses in nerve terminals. $A$, The upperimages are of an OGB-loaded type 1 b nerveterminal attime $=0$ [stimulation(stim)], 0.25 , and $0.4 \mathrm{~s}$. The red arrow and white lines indicate the location of the line scans through thenerveterminal. The lower image is a composite of all of the line scan images through the same location of the nerve terminal.Aii, The fluorescence of the sequential line scans is graphed below the composite image. Decay of the calcium transientresponsewasfitwith asingleexponential using the equation $y=a e^{-b x}$ (redline). Scaletotheright ofthescan representsincreasing fluorescence intensity. Red arrowindicates time of stimulation. $\boldsymbol{B}$, Increasing extracellular $\left[\mathrm{Ca}^{2+}\right]$ increases amplitude ofsingleimpulse $\mathrm{Ca}^{2+}$ responses. Normalized amplitudes of single impulse $\mathrm{Ca}^{2+}$ responses increased significantly $(p=0.01 ; n=6)$ with progressively increasing extracelIular $\mathrm{Ca}^{2+}$ concentration (open triangles): $0.138 \pm 0.010$ at $1.25 \mathrm{~mm} \mathrm{Ca}^{2+}, 0.160 \pm 0.015$ at $1.5 \mathrm{~mm}$ $\mathrm{Ca}^{2+}, 0.176 \pm 0.012$ at $2.0 \mathrm{~mm} \mathrm{Ca}^{2+}$, and ${ }^{+}$was $0.194 \pm 0.019$ at $4.0 \mathrm{~mm} \mathrm{Ca}^{2+}$. The time constant of decay recorded in preparations bathed in $1.25 \mathrm{~mm}\left[\mathrm{Ca}^{2+}\right]_{\mathrm{e}}$ was $46.2 \pm 6.1 \mathrm{~ms}$ and was not significantly different when recorded in $4.0 \mathrm{~mm}\left[\mathrm{Ca}^{2+}\right]_{\mathrm{e}^{\prime}}$ which was $54.3 \pm 6.5 \mathrm{~ms}$. C, DPKQDFMRFamide reversibly increases the amplitude of evoked calcium responses in presynaptic terminals. Ci, At 1.25 mm extracellular $\mathrm{Ca}^{2+}$, amplitude of the normalized evoked response significantly increased after peptide application ( $p<$ $0.05 ; n=10$ ). Washout (wash) of the peptide restored the amplitude, which was significantly less than with the peptide $(p<0.05)$. Cii, In 2.0 mm extracellular $\mathrm{Ca}^{2+}$, the normalized amplitude of the evoked response increased significantly with peptide application $(p<0.05 ; n=10)$ and reversed with washout of the peptide $(p>0.05)$. Ciii, Decay time constant was not altered by the peptide at $1.25 \mathrm{~mm} \mathrm{Ca}^{2+}(p=0.8)$. Civ, Decay time constant was not altered by the peptide at $2.0 \mathrm{~mm} \mathrm{Ca}^{2+}(p=0.9)$. ctrl, Control.D,DPKQD FMRFamide does not alter steady-state free intracellular $\left[\mathrm{Ca}^{2+}\right]$. Di, Ratiometric recordings of Fura fluorescence were made at 340 and $380 \mathrm{~nm}$ every $5 \mathrm{~s}$ for $15 \mathrm{~s}$, allowing quantification of $\left[\mathrm{Ca}^{2+}\right]$ at rest. Dii, No difference in resting or steady-state calcium levels is detected between control and DPKQDFMRFamideexposed nerve terminals $(n=4 ; p>0.6)$. pre, Pre-DPKQDFMRFamide. Asterisks $\left(^{*}\right)$ indicate significant difference.
Resting levels of calcium (cytosolic steady-state free calcium concentration) in nerve terminals were recorded using the fluorescent ratiometric calcium indicator Fura-dextran at 340 and $380 \mathrm{~nm}$ (Fig. 3Di). Ratiometric recordings were taken every $5 \mathrm{~s}$ for $15 \mathrm{~s}$, allowing quantification of $\mathrm{Ca}^{2+}$ concentration at rest. Resting $\mathrm{Ca}^{2+}$ concentration was $36.5 \pm 8.0 \mathrm{~nm}$ and, following application of the peptide, $42.2 \pm 7.0 \mathrm{~nm}$, which was not significantly different from the control (Fig. 3Dii). Thus, the peptide did not affect resting $\left[\mathrm{Ca}^{2+}\right]$, which is consistent with the lack of effect of the peptide on mEJC frequency (Table 1).

\section{Role of $\mathrm{Ca}^{2+}$-induced $\mathrm{Ca}^{2+}$ release}

Calcium-induced $\mathrm{Ca}^{2+}$ release (CICR) occurs following the activation of calcium-sensitive receptors on the ER membrane. CICR can modulate synaptic function during prolonged highfrequency activity in which $\mathrm{Ca}^{2+}$ influx through voltageactivated $\mathrm{Ca}^{2+}$ channels accumulates to levels that activate ryanodine and/or $\mathrm{IP}_{3}$ receptors (Llano et al., 2000).

To test for a role of intracellular $\mathrm{Ca}^{2+}$ stores in peptideinduced modulation of the $\mathrm{Ca}^{2+}$ response, we used Drosophila with a temperature-sensitive SERCA mutation that allows depletion of calcium stored in the endoplasmic reticulum. Evoked $\mathrm{Ca}^{2+}$ response amplitude in $\mathrm{CaP} 60 \mathrm{~A}^{\mathrm{Kum} 170}$ mutants was dramatically increased following temperature-induced inactivation of SERCA (Fig. 4A). Control CaP60A ${ }^{\text {Kuml70 }}$ response amplitude was $0.164 \pm 0.007$, and the time constant of decay was $51.2 \pm 7.3$ ms. Following the inactivation of SERCA function with a heat shock treatment, but before $\mathrm{Ca}^{2+}$ stores were depleted, $\mathrm{Ca}^{2+}$ response amplitude increased significantly to $0.416 \pm 0.029$, and the time constant of decay increased significantly to $124.1 \pm 24.2$ ms (Fig. $4 B, C$ ). Preparations were subsequently stimulated at high frequency for several minutes to deplete the ER of remaining $\mathrm{Ca}^{2+}$ stores. Following this depletion, both amplitude and time constant of decay were restored to control levels, and subsequent application of DPKQDFMRFamide did not significantly increase the amplitude of evoked responses at $2 \mathrm{~Hz}$ stimulation (Fig. 4C). Thus, release of intracellular $\mathrm{Ca}^{2+}$ from the ER stores is necessary for DPKQDFMRFamide-induced modulation of presynaptic $\mathrm{Ca}^{2+}$ responses.

Calcium release from the ER can occur through the calciumsensitive ryanodine receptor or through the $\mathrm{IP}_{3}$ receptor (Streb et al., 1983; Bardo et al., 2006). Inositol 1,4,5-trisphosphate is a second messenger made by hydrolysis of phosphatidylinositol 4,5-bisphosphate, a phospholipid that is located in the plasma membrane (Venkatesh and Hasan, 1997). IP ${ }_{3}$ binds to and activates the $\mathrm{Ins}_{3}$ receptor on the membrane of the ER, opening a $\mathrm{Ca}^{2+}$ channel which results in the release of $\mathrm{Ca}^{2+}$ into the cytoplasm. This increase in $\mathrm{Ca}^{2+}$ can activate the ryanodine receptoroperated channel on the ER, leading to a further increase in the $\mathrm{Ca}^{2+}$ response. Xestospongin $\mathrm{B}$ is a membrane-permeable selective antagonist of $\mathrm{IP}_{3}$ receptors (Bardo et al., 2006). The amplitude of evoked responses at $2 \mathrm{~Hz}$ in preparations bathed in xestospongin $B$ was $0.180 \pm 0.009$ and was not different from that of controls (Fig. 5A). DPKQDFMRFamide, in the presence of xestospongin $\mathrm{B}$, had no significant effect on response amplitude (Fig. 5Aii). Two $\mathrm{IP}_{3}$ receptor mutants, $P\{P Z\} I t p-r 83 A^{05616}$ ry506 $\left(I P_{3} R^{05616}\right)$ and $P\{E P g y 2\} I t p-r 83 A^{E Y 02522}\left(I P_{3} R^{E Y 02522}\right)$, were also tested for sensitivity to the peptide. Both the $I P_{3} R^{0561}$ and $I P_{3} R^{E Y 02522}$ mutants exhibited a decrease in $\mathrm{IP}_{3}$ receptor transcript levels (supplemental Fig. 1, available at www.jneurosci.org as supplemental material). Nerve terminals from both $\mathrm{IP}_{3}$ receptor mutant lines revealed a loss of the measured response to the peptide (Fig. 5Ai). Ryanodine (a plant alkaloid that interferes 

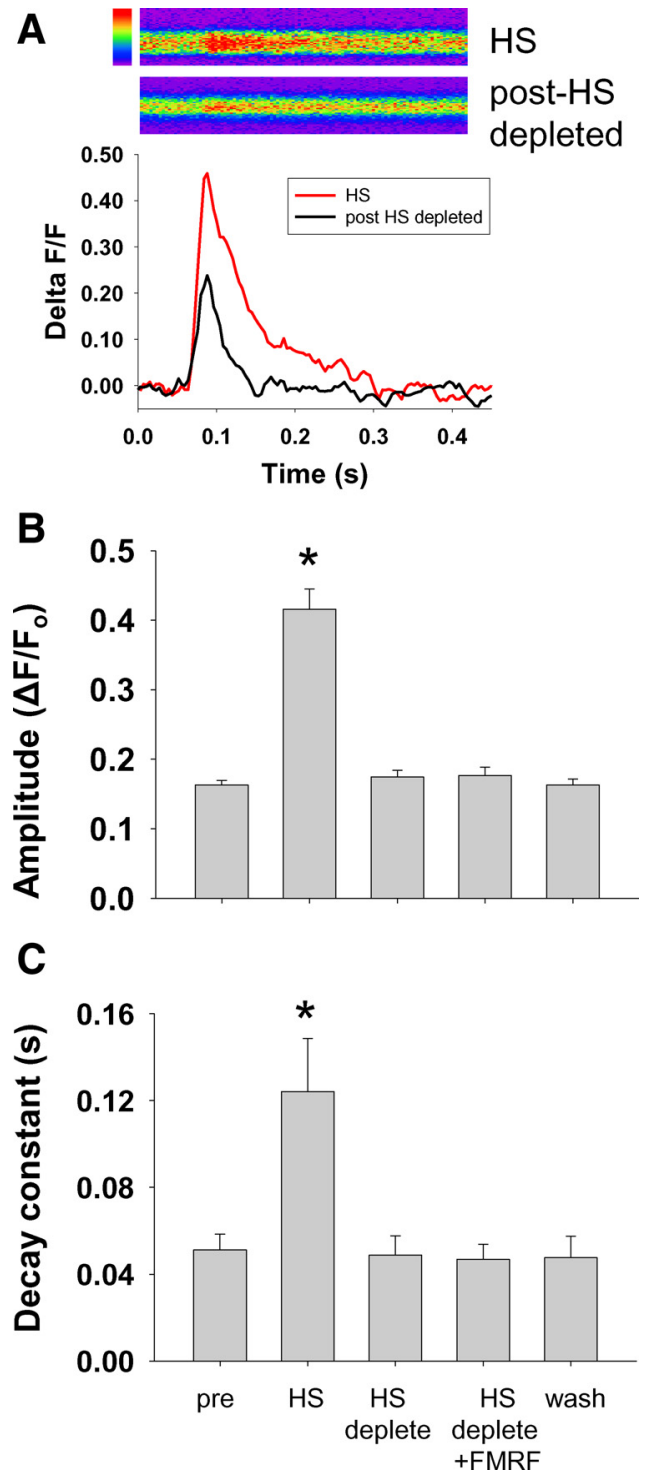

Figure 4. Depletion of $\mathrm{ER} \mathrm{Ca}^{2+}$ stores prevents peptide-induced modulation. Drosophila larvae with a conditional dominant negative temperature-sensitive SERCA mutation were used to test for a role of intracellular $\mathrm{Ca}^{2+}$ stores in DPKQDFMRFamide-induced modulation of evoked $\mathrm{Ca}^{2+}$ release. $\boldsymbol{A}$, Normalized amplitude of evoked $\mathrm{Ca}^{2+}$ responses in $\mathrm{CaP}^{2} 0 \mathrm{~A}^{\mathrm{Kum} 170}$ mutants under control conditions (black) and with inactivated SERCA (red) following an $8 \mathrm{~min}$ heat shock (HS) at $40^{\circ} \mathrm{C}$. Each trace is the average of four consecutive responses during a $2 \mathrm{~Hz}$ train and averaged every $20 \mathrm{~ms}$. $\boldsymbol{B}$, Following inactivation of SERCA function, normalized amplitude increased dramatically $(p<0.001 ; n=5)$. ER $\mathrm{Ca}^{2+}$ stores were depleted after $\sim 2$ min of $30 \mathrm{~Hz}$ stimulation. Following this depletion, response amplitudes reduced to control levels ( $p=0.001$ ). Subsequent application of DPKQDFMRFamide did not significantly alter the amplitude of evoked responses $(p=0.9)$. C, The decay constant was significantly increased following inactivation of SERCA but was restored to control levels following the depletion of calcium stores from the ER. Application of the peptide had no effect on decay constant in terminals with depleted ER calcium stores. pre, Pre-DPKQDFMRFamide. Asterisks (*) indicate significant difference.

with the receptor responsible for calcium-induced calcium release) at $100 \mu \mathrm{M}$ was used to block $\mathrm{Ca}^{2+}$-induced calcium release from the ER as done previously in Drosophila type $1 \mathrm{~b}$ nerve terminals (Shakiryanova et al., 2007). Stimulus-evoked $\mathrm{Ca}^{2+}$ responses in the nerve terminals of both $w-; P\{$ lacW $\}$ Rya$r 44 F k 04913 /+$ larvae and those exposed to ryanodine were not significantly altered by DPKQDFMRFamide (Fig. 5Ai,Aii). The time constant of decay was not altered by either ryanodine or
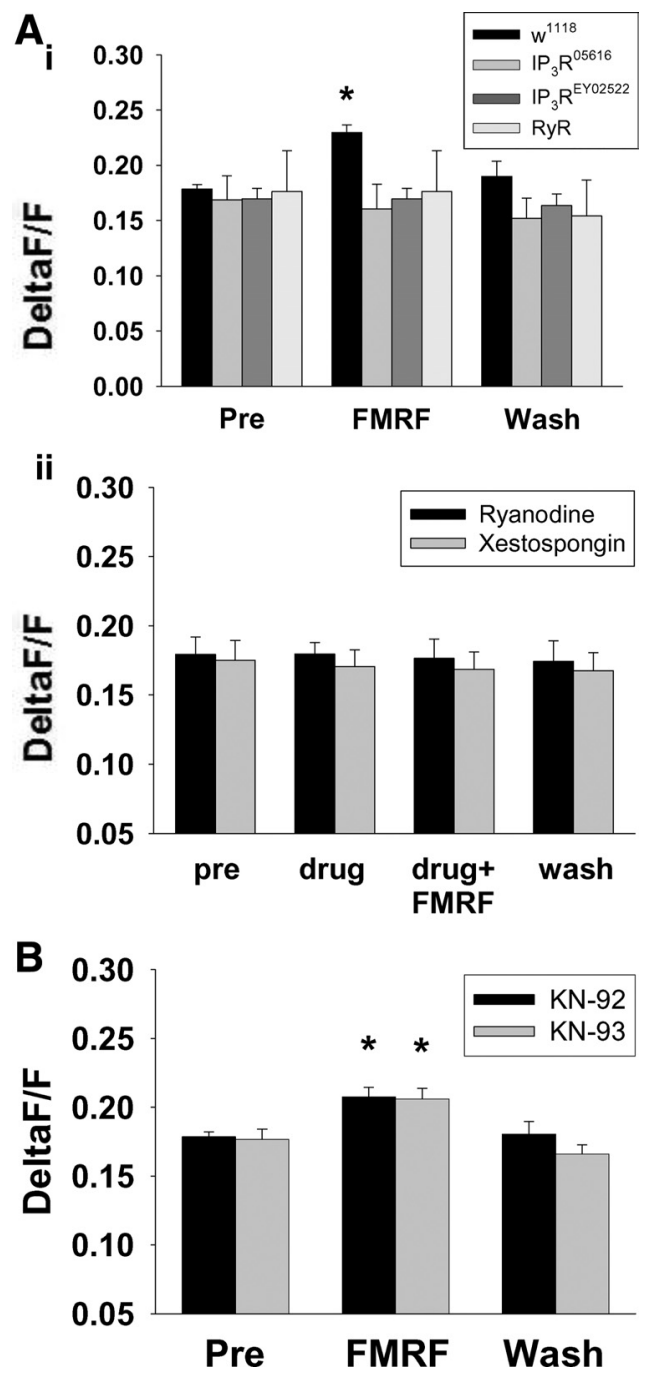

Figure 5. Peptide-induced modulation of calcium response mitigated by disruption of $I P_{3}$ or ryanodine receptor but not CaMKII. Ai, Genetic disruption of $I_{3}\left(I P_{3} R^{0561}\right.$ and $\left.I P_{3} R^{E Y 02522}\right)$ or ryanodine receptor (RyR) prevented the DPKQDFMRFamide-induced increase in calcium response amplitude observed in $w^{1118}$ controls. Aii, Pharmacological disruption of $\mathrm{IP}_{3}$ receptors with $100 \mathrm{~nm}$ xestospongin $\mathrm{B}$ or disruption of ryanodine receptors with $100 \mu \mathrm{m}$ ryanodine also mitigated the peptide-induced increase in calcium response amplitude observed in controls (see Fig. 2). B, Pharmacological disruption of CaMKII with $1 \mu \mathrm{m} \mathrm{KN-93} \mathrm{had} \mathrm{no} \mathrm{effect} \mathrm{on} \mathrm{peptide-}$ induced modulation of calcium response amplitude. The inactive analog KN-92 also had no effect on calcium responses. Pre, Pre-DPKQDFMRFamide. Asterisks $\left(^{*}\right)$ indicate significant difference.

xestospongin B, revealing that calcium clearance was not altered (data not shown). Disrupting release of calcium from internal stores using either $\mathrm{IP}_{3}$ or ryanodine receptor mutants also prevented the peptide-induced modulation of synaptic transmission (data not shown). Thus, release of calcium from intracellular stores through both the ryanodine and $\mathrm{IP}_{3}$ receptors is required for the DPKQDFMRFamide-mediated modulation of synaptic function.

\section{Role of CaMKII}

Previous studies have suggested that CaMKII is involved in peptide-mediated modulation of synaptic function (Dunn and Mercier, 2005; Shakiryanova et al., 2007). We tested CaMKII for a role in DPKQDFMRFamide-induced synaptic modulation. The peptide-induced increase in excitatory junctional potential amplitude can be suppressed by the CaMKII blocker KN-93 
(supplemental Fig. 3, available at www. jneurosci.org as supplemental material). We also tested whether CaMKII has a role in DPKQDFMRFamide-induced modulation of presynaptic $\mathrm{Ca}^{2+}$ responses by applying the pharmacological blocker KN-93 and its inactive analog KN-92 to the preparations. Neither agent modulated presynaptic $\mathrm{Ca}^{2+}$ response amplitude alone, but when DPKQDFMRFamide was applied in combination with either $\mathrm{KN}-93$ or $\mathrm{KN}-92, \mathrm{Ca}^{2+}$ response amplitude increased significantly (Fig. 5B). Thus, the peptide-induced modulation of evoked presynaptic $\mathrm{Ca}^{2+}$ response amplitude is not sensitive to CaMKII disruption.

\section{Modulation of behavior}

Drosophila larvae respond to bright light by moving away from the source (Caldwell et al., 2003), and they crawl more often and faster in response to temperature elevations. (Klose et al., 2005) (Fig. 6Ai,Aii). This escape response protects larvae from desiccation. We used a bright high temperature light $\left(34-36^{\circ} \mathrm{C}\right)$ and measured locomotor activity to determine whether DPKQDFMRFamide plays a role in the escape response. Distance traveled under room temperature and low light conditions by $w^{1118}$ larvae was $2.83 \pm 0.43 \mathrm{~cm}$ and not different from a mutant of the FmrfReceptor $\left(F R^{M B O 4659}\right)$, which traveled $2.70 \pm 0.36 \mathrm{~cm}$ in the same time period. However, under bright light conditions the mutant larvae traveled $4.20 \pm 0.59 \mathrm{~cm}$, which is significantly less than controls $6.71 \pm 0.65 \mathrm{~cm}$ (Fig. 6Ai,Aii). The escape response (percentage increase in locomotor activity induced by intense light exposure) was $194.6 \pm 60.2 \%$ in the background control $w^{1118}$. Both of the GPCRs known to be sensitive to DPKQDFMRFamide, the Fmrf Receptor $\left(F R^{M B O 4659}\right)$ and the Dromyosuppressin receptor-2 (DmsR-2 $2^{M B O 5984}$ ) (Johnson et al., 2003), were tested for roles in responses to the bright light. In $F R^{M B O 465}$ the locomotor response was $66.08 \pm 20.71 \%$, while in DmsR-2 $2^{M B O 5984}$ it was $53.6 \pm 8.5 \%$, both of which were significantly less than in the control (Fig. 6Bi). We also examined the Dromyosuppressin receptor-1, which belongs to the same neurotensin/thyrotropinreleasing factor receptor family as the FR and DmsR-2 (Hewes and Taghert, 2001) but has only been shown to be sensitive to dromyosuppressin and not DPKQDFMRFamide (Johnson et al., 2003). In these mutants $\left(D m s R-1^{\text {EYO3017}}\right)$ the light-induced increase in distance traveled was $195.4 \pm 51.7 \%$ and was not different from $w^{1118}$ larvae (Fig. 6Bi). The data reveal that both the FR and the DmsR-2 receptors, but not the DmsR-1 receptor, are necessary for the escape response and suggest that DPKQDFMRFamide is regulating the response.

The reduced behavioral phenotype was also observed with targeted knockdown of either the Fmrf receptor or the Dromyosuppressin receptor-2. The normal increase in locomotor activity occurring during the escape response was significantly reduced in
UAS FR RNAi $\times$ elav-Gal4 larvae to $62.0 \pm 15.3 \%$ when compared with the controls; UAS FR RNAi increased by $197.7 \pm$ $31.7 \%$ and elav-Gal4 increased by $212.6 \pm 47.5 \%$. The increase in activity in UAS DmsR RNAi × elav-Gal4 was also significantly reduced to $73.2 \pm 19.5 \%$ compared with controls; UAS DmsR $R N A i$ increased by $201.5 \pm 52.8 \%$. RNAi knockdown of $F R$ in muscles, UAS FR RNAi $\times 24 b$-Gal4, resulted in a $199.2 \pm 38.4 \%$ increase in activity and was not different from either control: $24 b$ Gal4, which was $207.8 \pm 40.9 \%$, or the UAS FR RNAi. Likewise, RNAi knockdown of DmsR-2 in muscles, UAS DmsR-2 RNAi $\times$ $24 b$-Gal4, exhibited $225.4 \pm 54.7 \%$ in activity, which was also not different from controls: UAS DmsR-2 RNAi or 24b-Gal4. Thus, RNAi knockdown of either receptor in nerves, but not in muscles, mimicked the behavioral phenotype observed in mutants of the same receptors, supporting a role for each receptor in regulating behavior (Fig. $6 \mathrm{Bii}$ ). The data also suggest that previously observed activity of this peptide at the neuromuscular junction (Hewes et al., 1998) acts via GPCRs located presynaptically on the nerve. 
$A_{i}$
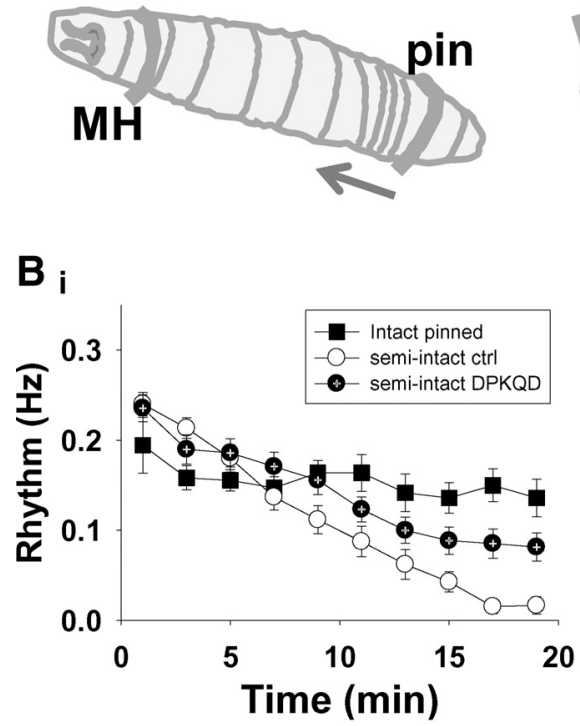

ii

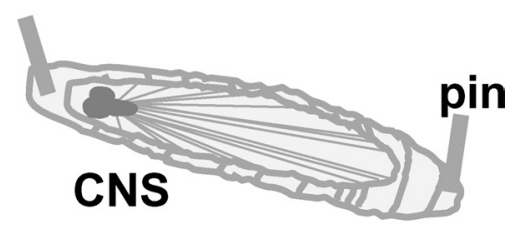

ii

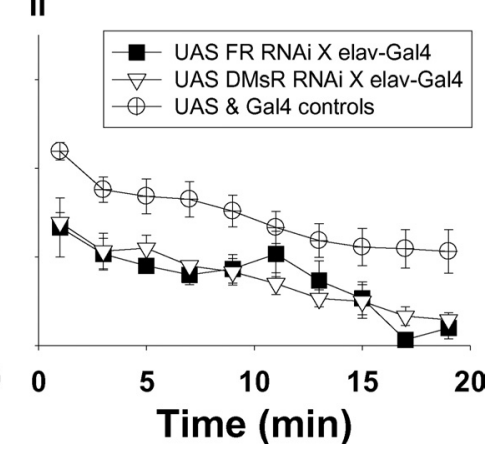

Figure 7. DPKQDFMRFamide partially restores propensity for fictive locomotion. $\boldsymbol{A}$, Diagram of restrained third instar wandering larvae attempting to crawl (arrow indicates direction of peristaltic wave of locomotor muscle contractions). The rhythm frequency (number of contractions per second averaged over consecutive 2 min time bins) during a 20 min recording period was examined in both intact $(\boldsymbol{A i})$ and semi-intact larvae (Aii). Bi, Rhythm frequency remained stable in pinned intact larvae $(n=6)$ but decreased steadily in semi-intact larvae following replacement of hemolymph with the hemolymph-like saline HL3 and, after 20 min, was significantly reduced $(n=20 ; p>0.001)$. When hemolymph-like saline contained $\left(5 \times 10^{-6} \mathrm{M}\right)$ peptide, the rhythm frequency in the semi-intact larvae was significantly higher than without peptide $(n=20 ; p=0.002)$ and significantly lower than in intact larval preparations ( $p<0.05$ ). Bii, RNAi interference of either DPKQDFMRFamide-sensitive receptor mitigated the peptide-induced partial rescue of fictive locomotor activity. The fictive rhythm in genetic control lines was significantly higher than both UAS FR $R^{M B 04659} \times$ elav-Gal4 $(p=0.02)$ and UAS DmsR-2 $2^{M B 05984} \times$ elav-Gal4 $(p>0.05)$. UAS and Gal-4 lines were combined because they were not significantly different at any time point (circle, $n=10$; square, $n=5$; triangle, $n=5$ ). $\mathrm{MH}$, Mouth hooks.

To examine the effects of DPKQDFMRFamide on locomotor activity in the absence of other neuroactive substances, we used a fictive locomotion assay that allowed replacement of the hemolymph with hemolymph-like saline (Fig. 7Ai,Aii). Larvae respond to elevated temperature by increasing the frequency of their rhythmic contractions, resulting in an increase in distance traveled per unit time (Klose et al., 2005). Thus, we used the frequency of peristaltic waves in pinned larvae as a measure of locomotor activity. Pinned intact larvae attempted to crawl every 5-7 s. The peristaltic frequency remained stable following pinning, beginning at $0.19 \pm 0.03 \mathrm{~Hz}$ and remaining at $0.14 \pm 0.21$ $\mathrm{Hz} 20 \mathrm{~min}$ later, which was not significantly different. The fictive locomotor rhythm of semi-intact larvae in which the hemolymph was replaced with hemolymph-like saline was initially $0.21 \pm 0.17$ $\mathrm{Hz}$ but diminished significantly over a $20 \mathrm{~min}$ period to $0.02 \pm 0.01$ $\mathrm{Hz}$, presumably due to the removal of endogenous hormones and neuromodulators. In those preparations bathed in DPKQDFMRFamide $\left(5 \times 10^{-6} \mathrm{M}\right)$ for $20 \mathrm{~min}$, the frequency of fictive locomotor activity was partially restored to $0.08 \pm 0.02 \mathrm{~Hz}$, significantly higher than without the peptide. RNAi knockdown of either receptor sensitive to DPKQDFMRFamide mitigated the peptide-induced enhancement of fictive locomotor activity observed in wild-type preparations. The fictive rhythm in genetic control lines was $0.106 \pm$ 0.025 after $20 \mathrm{~min}$ of exposure to the peptide $\left(5 \times 10^{-6} \mathrm{M}\right)$, significantly higher than both UAS FR ${ }^{M B O 4659} \times$ elav-Gal4, which was $0.013 \pm 0.013 \mathrm{~Hz}$, and UAS DmsR-2 $2^{M B O 5984} \times$ elav-Gal4, which was $0.025 \pm 0.01$ (Fig. 7Bii). Thus, our data suggest that the neuropeptide DPKQDFMRFamide acts via two GPCRs, FR and DmsR-2, both expressed in neurons, to control the escape response in Drosophila larvae.

\section{Discussion}

We have investigated the mechanisms by which the neuropeptide DPKQDFMRFamide modulates synaptic function and behavior. We show that DPKQDFMRFamide signaling through both the FR and the $D m s R-2$ is required for the peptideinduced modulation of synaptic transmission and an escape response in Drosophila. At peripheral synapses we show the GPCR activation by DPKQDFMRFamide increases the amplitude of both $\mathrm{Ca}^{2+}$ transients and quantal content per nerve stimulus. Modulation of the active $\mathrm{Ca}^{2+}$ response occurred regardless of extracellular $\mathrm{Ca}^{2+}$ concentration but was abrogated by depleting intracellular $\mathrm{Ca}^{2+}$ stores or by interfering with $\mathrm{Ca}^{2+}$ release from these stores. We provide evidence suggesting that DPKQDFMRFamideinduced modulation of calcium regulation results from enhanced $\mathrm{Ca}^{2+}$-induced $\mathrm{Ca}^{2+}$ release from the endoplasmic reticulum involving the combined activity of both $\mathrm{IP}_{3}$ receptor and ryanodine receptor function. Thus, we show that DPKQDFMRFamide modulates behavior, transmitter release, and intracellular calcium handling through two GPCRs.

Several Drosophila G-protein coupled receptors sensitive to FMRFamides have been deorphaned using cell culture assays (Cazzamali and Grimmelikhuijzen, 2002; Nichols, 2006). For the majority of these receptors, little is known of the role they play in regulating behavior and what cellular pathways they modulate. Both the FR and the DmsR-2 were necessary for the peptide-mediated modulation at the neuromuscular junction. Meeusen et al. (2002) suggested that in Drosophila only one FMRFamide receptor, CG2114, is encoded by the genome since alignment of $C G 2114$ with the closest related receptor genes (CG5911, CG13803, CG8985, and CG5936) yielded only $11-14 \%$ sequence identity. Subsequent analysis of these orphan receptors in cell culture using the $\beta$-arrestin GFP translocation assay revealed that both CG2114 (FR) and CG13803 (DmsR-2) are sensitive to DPKQDFMRFamide. GPCRs can dimerize to form complex signaling molecules (Woehler and Ponimaskin, 2009), which may explain why both GPCRs, the FR and the $D m s R-2$, were required for DPKQDFMRFamide-enhanced transmitter release. The full complement of GPCRs has yet to be thoroughly characterized. At least 13 FMRFamide-like peptides exist in Drosophila (Schneider and Taghert, 1988), and it is therefore conceivable that other FMRFamide receptors may be found.

Activation of the FR and DmsR-2 by DPKQDFMRFamide modulates intracellular calcium handling. Calcium triggers neurotransmitter release and plays a central role in various forms of modulation. Increased neural activity causes increased $\mathrm{Ca}^{2+} \mathrm{ac}-$ cumulation that activates target proteins, enhancing transmitter release (Zucker, 1996; de Jong and Verhage, 2009). Most investigations of presynaptic modulation have focused on calcium channel modulation (Man-Son-Hing et al. 1989; Rathmayer et al. 2002; Gundlfinger et al. 2007; Donato et al. 2008; Leal and Klein, 2009; Sánchez-Mejorada et al. 2009). Some evidence has sug- 
gested that FMRFamide can alter the calcium-sensitivity of the secretory apparatus (Man-Son-Hing et al. 1989); however, effects on $\mathrm{Ca}^{2+}$-induced $\mathrm{Ca}^{2+}$ have been scantily examined. One study examined the effect of cholecystokinin on glutamate release in hippocampal granule cells and revealed a modulatory role for $\mathrm{IP}_{3}$ receptor function (Deng et al., 2010), but it did not examine a role for ryanodine receptors. In mammalian hippocampal and cerebellar synapses, involvement of CICR in short-term facilitation has been suggested (Emptage et al., 2001; Bardo et al., 2006), although this remains somewhat controversial (Carter et al., 2002). A body of literature indicates that peptides modulate the slow secretion of neuroactive substances from pancreatic $\beta$-cells (Zhang et al., 2007). Here, we show that initiation of CICR by a peptidergic hormone can modulate fast transmission at a glutamatergic synapse. We found that depletion of ER calcium stores prevented DPKQDFMRFamide-induced modulation of $\mathrm{Ca}^{2+}$ transients. Thus, we suggest that the peptide activates pathways that sensitize the $\mathrm{Ca}^{2+}$ store to activation by residual $\mathrm{Ca}^{2+}$ following action potential invasion of the nerve terminal. This allows sufficient $\mathrm{Ca}^{2+}$ release to supersede the capacity of the SERCA pumps and local buffering proteins to activate neuromodulatory pathways.

Clusters of $\mathrm{IP}_{3}$ receptors create local signals known as $\mathrm{Ca}^{2+}$ "puffs," whereas ryanodine receptors produce $\mathrm{Ca}^{2+}$ "sparks." These $\mathrm{Ca}^{2+}$ signals produce moderate elevations in $\mathrm{Ca}^{2+}$ concentration with a typically limited spatial spread (Berridge et al., 2003; Xu et al., 2009). In Xenopus oocytes, $\mathrm{Ca}^{2+}$ that is released by a cluster of receptors can diffuse to adjacent receptors, resulting in saltatoric propagation of the initial signal to trigger global $\mathrm{Ca}^{2+}$ waves and oscillations (Yao et al., 1995; Sun et al., 1998). It is conceivable that a similar propagation of calcium from a set of $\mathrm{IP}_{3}$ receptors to a set of ryanodine receptors is occurring in the confines of the Drosophila nerve terminal. This might explain why disruption of either receptor results in the loss of the modulation rather than a partial attenuation. How CICR is modulated by DPKQDFMRFamide is unclear. Because both the $\mathrm{IP}_{3}$ and ryanodine receptors are required for the peptide's effect, it is unclear whether one or both of these intracellular receptors is being modulated following activation of the GPCRs. Regardless, the peptide modulates $\mathrm{Ca}^{2+}$-induced $\mathrm{Ca}^{2+}$ release, activating modulatory pathways leading to enhanced transmitter release.

CaMKII plays a role in DPKQDFMRFamide-dependent modulation of transmitter release. Disruption of CaMKII disrupted the peptide-induced modulation of synaptic transmission; however, it did not prevent peptide-induced modulation of presynaptic $\mathrm{Ca}^{2+}$ responses. Thus, we suggest a role for CaMKII following release of internal $\mathrm{Ca}^{2+}$ stores and before vesicle exocytosis. The modulatory effects on presynaptic calcium handling reversed within $5 \mathrm{~min}$ of washing out the peptide, while the postsynaptically recorded effects persisted long afterward. CaMKII is autophosphorylated following $\mathrm{Ca}^{2+} /$ calmodulin activation, resulting in an increased affinity for the calmodulin complex, prolonging the time that the kinase is active (Hodge et al., 2006). In addition, autonomic activity of the phosphorylated kinase complex, even after the calmodulin complex has dissociated from the complex, further prolongs the active state (Hudmon and Schulman, 2002). Interestingly, neurotransmitter release is enhanced by ryanodine receptor-activated CaMKII activity in these nerve terminals (Shakiryanova et al., 2007), which could explain the observed postsynaptic effects of the peptide (supplemental Fig. 4, available at www.jneurosci.org as supplemental material). Several other second messengers are likely involved in conferring the effects of the peptide on transmitter release. In
Aplysia, presynaptic facilitation induced by FMRFamide in sensory neurons of the gill-withdrawal reflex and siphon-withdrawal reflex acts via cAMP (Mackey et al., 1987), while in crustaceans, FMRFamide-like peptides act through both cAMP and cGMP (Badhwar et al., 2006). $\mathrm{IP}_{3}$ receptors are phosphorylated by cAMP-dependent protein kinase A (Soulsby and Wojcikiewicz, 2005) and could thus be involved in the peptide-induced modulation.

The increased transmitter release induced by DPKQDFMRFamide at the neuromuscular junction increases muscle force by 3.5-fold (Hewes et al., 1998). At the onset of a locomotor burst during the cycle, the transition between low and high neuromuscular activity is not instantaneous but rather increases progressively before peaking at $60 \mathrm{~Hz}$ when maximal force of the contraction is attained (Klose et al., 2005). The observed increase in transmitter released per action potential could expedite the rate at which maximal force is achieved, resulting in the observed increase in rate of locomotion. Interestingly, during the late third instar stage when FMRF mRNA levels increase, the larvae cease feeding and enter the wandering stage, which is characterized by increased locomotor activity (Sokolowski, 1980).

Although it has been previously suggested that FMRFamidelike peptide-induced modulation of arthropod neuromuscular synapses can result from modulation of $\mathrm{N}$-type calcium channels (Rathmayer et al., 2002), we provide strong evidence for an alternate modulatory pathway. An approximate third- or fourthpower relationship between transmitter release and calcium level at release sites suggests that changes in calcium influx are not responsible for the increased evoked calcium response (Jan and Jan, 1976; Robinson et al., 2002; Okamoto et al., 2005). Voltageactivated $\mathrm{Ca}^{2+}$ channels are located in high densities at active zones, the sites of active transmitter release; thus, if they were responsible for the increased $\mathrm{Ca}^{2+}$ response, the $20 \%$ increase in presynaptic $\mathrm{Ca}^{2+}$ signal observed would translate into a near doubling of EJP in the postsynaptic cell, which does not occur (Fig. 1). The present data suggest that DPKQDFMRFamide binds to $F R$ and $D m s R-2$, modulating calcium-induced $\mathrm{Ca}^{2+}$ release, which requires combined action of both ryanodine receptors and $\mathrm{IP}_{3}$ receptors. Since pharmacological disruption of CaMKII did not prevent the peptide from modulating the calcium response, the increased intracellular calcium signal likely activates CaMKII, resulting in the observed enhancement in release of neurotransmitter. In addition, modulation of a behavioral stress response also requires both the Fmrf receptor and the Dromyosupressin receptor-2. The increase in locomotor activity we observed results from a complex combination of centrally driven and peripherally regulated increases in output.

Several neuropeptides have been shown to play a role in modulating behavior in both invertebrates and mammals. Neuropeptide Y, secreted by the hypothalamus in mammals, reduces physical activity (de Bono and Bargmann, 1998), while neuropeptide $\mathrm{F}$, the invertebrate homolog, plays a similar role in Drosophila by reducing aggressive behavior (Dierick and Greenspan, 2007). Interestingly, both peptides have also been shown to regulate food intake (Sokolowski, 2003). Disruption of another neuropeptide in Drosophila, tachykinnin-related peptide, gives rise to hyperactive flies (Winther et al., 2006). Activation of FMRFamide-releasing cells has been correlated with ecdysis behavior (Kim et al., 2006), and FMRF inhibits egg laying in $C$. elegans (Ringstad and Horvitz, 2008). Activation of the GPCR, NPR-1, by its ligand FLP-21 regulates hypoxia-enhanced sensory perception, revealing a role for a FMRFamide-related neuropeptide in a stress-induced behavior (Pocock and Hobert, 2010). The 
present work demonstrates that DPKQDFMRFamide enhances fictive locomotion via two GPCRs and that these same GPCRs mediate the escape response. Drosophila larvae move away from light (Caldwell et al., 2003) and increase their crawling velocity with temperature elevations (Klose et al., 2005; Luo et al., 2010) (Fig. 6 Ai,6ii). Prolonged exposure to $36^{\circ} \mathrm{C}$ can activate the cellular heat shock response in Drosophila (Ritossa, 1962; Karunanithi et al., 1999); thus, the observed escape response to bright, high temperature light likely represents an adaptive behavioral stress response against the deleterious effects of sun exposure in the natural environment of the larvae.

\section{References}

Adams MD, Celniker SE, Holt RA, Evans CA, Gocayne JD, Amanatides PG, Scherer SE, Li PW, Hoskins RA, Galle RF, George RA, Lewis SE, Richards S, Ashburner M, Henderson SN, Sutton GG, Wortman JR, Yandell MD, Zhang Q, Chen LX, et al. (2000) The genome sequence of Drosophila melanogaster. Science 287:2185-2195.

Badhwar A, Weston AD, Murray JB, Mercier AJ (2006) A role for cyclic nucleotide monophosphates in synaptic modulation by a crayfish neuropeptide. Peptides 27:1281-1290.

Bardo S, Cavazzini MG, Emptage N (2006) The role of the endoplasmic reticulum $\mathrm{Ca}^{2+}$ store in the plasticity of central neurons. Trends Pharmacol Sci 27:78-84.

Berridge MJ, Bootman MD, Roderick HL (2003) Calcium signalling: dynamics, homeostasis and remodelling. Nat Rev Mol Cell Biol 4:517-529.

Bronk P, Nie Z, Klose MK, Dawson-Scully K, Zhang J, Robertson RM, Atwood HL, Zinsmaier KE (2005) The multiple functions of cysteinestring protein analyzed at Drosophila nerve terminals. J Neurosci 25:2204-2222.

Caldwell JC, Miller MM, Wing S, Soll DR, Eberl DF (2003) Dynamic analysis of larval locomotion in Drosophila chordotonal organ mutants. Proc Natl Acad Sci U S A 100:16053-16058.

Carter AG, Vogt KE, Foster KA, Regehr WG (2002) Assessing the role of calcium-induced calcium release in short-term presynaptic plasticity at excitatory central synapses. J Neurosci 22:21-28.

Cazzamali G, Grimmelikhuijzen CJ (2002) Molecular cloning and functional expression of the first insect FMRFamide receptor. Proc Natl Acad Sci U S A 99:12073-12078.

Chang AJ, Chronis N, Karow DS, Marletta MA, Bargmann CI (2006) A distributed chemosensory circuit for oxygen preference in C. elegans. PLoS Biol 4:e274.

Clark J, Milakovic M, Cull A, Klose MK, Mercier AJ (2008) Neuropeptide DPKQDFMRFamide acts postsynaptically. Peptides 29:1140-1149.

Dason JS, Romero-Pozuelo J, Marin L, Iyengar BG, Klose MK, Ferrús A, Atwood HL (2009) Frequenin/NCS-1 and the $\mathrm{Ca}^{2+}$ channel $\alpha_{1}$-subunit co-regulate synaptic transmission and nerve terminal growth. J Cell Sci 122:4109-4121.

de Bono M, Bargmann CI (1998) Natural variation in a neuropeptide Y receptor homolog modifies social behavior and food response in $C$. elegans. Cell 94:679-689.

de Jong AP, Verhage M (2009) Presynaptic signal transduction pathways that modulate synaptic transmission. Curr Opin Neurobiol 19:245-253.

Deng PY, Xiao Z, Jha A, Ramonet D, Matsui T, Leitges M, Shin HS, Porter JE, Geiger JD, Lei S (2010) Cholecystokinin facilitates glutamate release by increasing the number of readily releasable vesicles and releasing probability. J Neurosci 30:5136-5148.

Dierick HA, Greenspan RJ (2007) Serotonin and neuropeptide F have opposite modulatory effects on fly aggression. Nat Genet 39:678-682.

Donato R, Rodrigues RJ, Takahashi M, Tsai MC, Soto D, Miyagi K, Villafuertes RG, Cunha RA, Edwards FA (2008) GABA release by basket cells onto Purkinje cells, in rat cerebellar slices, is directly controlled by presynaptic purinergic receptors, modulating $\mathrm{Ca}^{2+}$ influx. Cell Calcium 44:521-532.

Dunn TW, Mercier AJ (2005) Synaptic modulation by a Drosophila neuropeptide is motor neuron-specific and requires CaMKII activity. Peptides 26:269-276.

Eade KT, Allan DW (2009) Neuronal phenotype in the mature nervous system is maintained by persistent retrograde bone morphogenetic protein signaling. J Neurosci 29:3852-3864.

Emptage NJ, Reid CA, Fine A (2001) Calcium stores in hippocampal synap- tic boutons mediate short-term plasticity, store-operated $\mathrm{Ca}^{2+}$ entry, and spontaneous transmitter release. Neuron 29:197-208.

Espinoza E, Carrigan M, Thomas SG, Shaw G, Edison AS (2000) A statistical view of FMRFamide neuropeptide diversity. Mol Neurobiol 21:35-56.

Gloria-Soria A, Azevedo RB (2008) npr-1 regulates foraging and dispersal strategies in Caenorhabditis elegans. Curr Biol 18:1694-1699.

Greenberg MJ, Price DA (1992) Relationships among the FMRFamide-like peptides. Prog Brain Res 92:25-37.

Grynkiewicz G, Poenie M, Tsien RY (1985) A new generation of $\mathrm{Ca}^{2+}$ indicators with greatly improved fluorescence properties. J Biol Chem 260:3440-3450.

Gundlfinger A, Leibold C, Gebert K, Moisel M, Schmitz D, Kempter R (2007) Differential modulation of short-term synaptic dynamics by long-term potentiation at mouse hippocampal mossy fibre synapses. J Physiol 585:853-865.

Hewes RS, Taghert PH (2001) Neuropeptides and neuropeptide receptors in the Drosophila melanogaster genome. Genome Res 11:1126-1142.

Hewes RS, Snowdeal EC 3rd, Saitoe M, Taghert PH (1998) Functional redundancy of FMRFamide-related peptides at the Drosophila larval neuromuscular junction. J Neurosci 18:7138-7151.

Hoang B, Chiba A (2001) Single-cell analysis of Drosophila larval neuromuscular synapses. Dev Biol 229:55-70

Hodge JJ, Mullasseril P, Griffith LC (2006) Activity-dependent gating of CaMKII autonomous activity by Drosophila CASK. Neuron 51:327-337.

Hudmon A, Schulman H (2002) Structure-function of the multifunctional $\mathrm{Ca}^{2+}$ /calmodulin-dependent protein kinase II. Biochem J 364:593-611.

Jan LY, Jan YN (1976) Properties of the larval neuromuscular junction in Drosophila melanogaster. J Physiol 262:189-214.

Johnson EC, Bohn LM, Barak LS, Birse RT, Nässel DR, Caron MG, Taghert PH (2003) Identification of Drosophila neuropeptide receptors by G proteincoupled receptors- $\beta$-arrestin2 interactions. J Biol Chem 278:52172-52178.

Kaminski S, Orlowski E, Berry K, Nichols R (2002) The effects of three Drosophila melanogaster myotropins on the frequency of foregut contractions differ. J Neurogenet 16:125-134.

Karunanithi S, Barclay JW, Robertson RM, Brown IR, Atwood HL (1999) Neuroprotection at Drosophila synapses conferred by prior heat shock. J Neurosci 19:4360-4369.

Kim YJ, Zitnan D, Galizia CG, Cho KH, Adams ME (2006) A command chemical triggers an innate behavior by sequential activation of multiple peptidergic ensembles. Curr Biol 16:1395-1407.

Klose MK, Chu D, Xiao C, Seroude L, Robertson RM (2005) Heat shockmediated thermoprotection of larval locomotion compromised by ubiquitous overexpression of Hsp70 in Drosophila melanogaster. J Neurophysiol 94:3563-3572.

Klose MK, Atwood HL, Robertson RM (2008) Heat shock-induced thermoprotection of calcium regulation at Drosophila nerve terminals. J Neurophysiol 99:2420-2430.

Leal K, Klein M (2009) Direct enhancement of presynaptic calcium influx in presynaptic facilitation at Aplysia sensorimotor synapses. Mol Cell Neurosci 41:247-257.

Llano I, González J, Caputo C, Lai FA, Blayney LM, Tan YP, Marty A (2000) Presynaptic calcium stores underlie large-amplitude miniature IPSCs and spontaneous calcium transients. Nat Neurosci 3:1256-1265.

Lnenicka GA, Keshishian H (2000) Identified motor terminals in Drosophila larvae show distinct differences in morphology and physiology. J Neurobiol 43:186-197.

Luo L, Gershow M, Rosenzweig M, Kang K, Fang-Yen C, Garrity PA, Samuel AD (2010) Navigational decision making in Drosophila thermotaxis. J Neurosci 30:4261-4272.

Mackey SL, Glanzman DL, Small SA, Dyke AM, Kandel ER, Hawkins RD (1987) Tail shock produces inhibition as well as sensitization of the siphon-withdrawal reflex of Aplysia: possible behavioral role for presynaptic inhibition mediated by the peptide Phe-Met-Arg-Phe-NH2. Proc Natl Acad Sci U S A 84:8730-8734.

Macleod GT, Hegström-Wojtowicz M, Charlton MP, Atwood HL (2002) Fast calcium signals in Drosophila motor neuron terminals. J Neurophysiol 88:2659-2663.

Man-Son-Hing H, Zoran MJ, Lukowiak K, Haydon PG (1989) A neuromodulator of synaptic transmission acts on the secretory apparatus as well as on ion channels. Nature 341:237-239.

Meeusen T, Mertens I, Clynen E, Baggerman G, Nichols R, Nachman RJ, Huybrechts R, De Loof A, Schoofs L (2002) Identification in Drosophila 
melanogaster of the invertebrate $\mathrm{G}$ protein-coupled FMRFamide receptor. Proc Natl Acad Sci U S A 99:15363-15368.

Nichols R (2006) FMRFamide-related peptides and serotonin regulate Drosophila melanogaster heart rate: mechanisms and structure requirements. Peptides 27:1130-1137.

Okamoto T, Tamura T, Suzuki K, Kidokoro Y (2005) External Ca ${ }^{2+}$ dependency of synaptic transmission in Drosophila synaptotagmin I mutants. J Neurophysiol 94:1574-1586.

Panula P, Aarnisalo AA, Wasowicz K (1996) Neuropeptide FF, a mammalian neuropeptide with multiple functions. Prog Neurobiol 48:461-487.

Pocock R, Hobert O (2010) Hypoxia activates a latent circuit for processing gustatory information in C. elegans. Nat Neurosci 13:610-614.

Rathmayer W, Djokaj S, Gaydukov A, Kreissl S (2002) The neuromuscular junctions of the slow and the fast excitatory axon in the closer of the crab Eriphia spinifrons are endowed with different $\mathrm{Ca}^{2+}$ channel types and allow neuron-specific modulation of transmitter release by two neuropeptides. J Neurosci 22:708-717.

Ringstad N, Horvitz HR (2008) FMRFamide neuropeptides and acetylcholine synergistically inhibit egg-laying by C. elegans. Nat Neurosci 11:1168-1176.

Ritossa F (1962) A new puffing pattern induced by temperature shock and DNP in Drosophila. Experientia 18:571-573.

Robinson IM, Ranjan R, Schwarz TL (2002) Synaptotagmins I and IV promote transmitter release independently of $\mathrm{Ca}^{2+}$ binding in the $\mathrm{C}(2) \mathrm{A}$ domain. Nature 418:336-340.

Sánchez-Mejorada E, Sánchez-Mondragon G, Pineda JC, González M, Barral J (2009) N-type calcium channels mediate a $\mathrm{GABA}_{\mathrm{B}}$ presynaptic modulation in the corticostriatal synapse in turtle's paleostriatum augmentatum. Synapse 63:855-862.

Sanyal S, Consoulas C, Kuromi H, Basole A, Mukai L, Kidokoro Y, Krishnan KS, Ramaswami M (2005) Analysis of conditional paralytic mutants in Drosophila sarco-endoplasmic reticulum calcium ATPase reveals novel mechanisms for regulating membrane excitability. Genetics 169:737-750.

Schneider LE, Taghert PH (1988) Isolation and characterization of a Drosophila gene that encodes multiple neuropeptides related to Phe-MetArg-Phe- $\mathrm{NH}_{2}$ (FMRFamide). Proc Natl Acad Sci U S A 85:1993-1997.

Schneider LE, Sun ET, Garland DJ, Taghert PH (1993) An immunocytochemical study of the FMRFamide neuropeptide gene products in Drosophila. J Comp Neurol 337:446-460.

Shakiryanova D, Klose MK, Zhou Y, Gu T, Deitcher DL, Atwood HL, Hewes RS, Levitan ES (2007) Presynaptic ryanodine receptor-activated calmodulin kinase II increases vesicle mobility and potentiates neuropeptide release. J Neurosci 27:7799-7806.
Sokolowski MB (1980) Foraging strategies of Drosophila melanogaster: a chromosomal analysis. Behav Genet 10:291-302.

Sokolowski MB (2003) NPY and the regulation of behavioral development. Neuron 39:6-8.

Soulsby MD, Wojcikiewicz RJ (2005) The type III inositol 1,4,5 trisphosphate receptor is phosphorylated by cAMP-dependent protein kinase at three sites Biochem J 392:493-497.

Stewart BA, Atwood HL, Renger JJ, Wang J, Wu CF (1994) Improved stability of Drosophila larval neuromuscular preparations in hemolymphlike physiological solutions. J Comp Physiol A 175:179-191.

Streb H, Irvine RF, Berridge MJ, Schulz I (1983) Release of $\mathrm{Ca}^{2+}$ from a nonmitochondrial intracellular store in pancreatic acinar cells by inositol-1,4,5-trisphosphate. Nature 306:67-76.

Sun XP, Callamaras N, Marchant JS, Parker I (1998) A continuum of InsP3mediated elementary $\mathrm{Ca}^{2+}$ signalling events in Xenopus oocytes. J Physiol 509:67-80.

Tank DW, Regehr WG, Delaney KR (1995) A quantitative analysis of presynaptic calcium dynamics that contribute to short-term enhancement J Neurosci 15:7940-7979.

Venkatesh K, Hasan G (1997) Disruption of the IP3 receptor gene of Drosophila affects larval metamorphosis and ecdysone release. Curr Biol 7:500-509.

Vilim FS, Sasaki K, Rybak J, Alexeeva V, Cropper EC, Jing J, Orekhova IV, Brezina V, Price D, Romanova EV, Rubakhin SS, Hatcher N, Sweedler JV, Weiss KR (2010) Distinct mechanisms produce functionally complementary actions of neuropeptides that are structurally related but derived from different precursors. J Neurosci 30:131-147.

Winther AM, Acebes A, Ferrús A (2006) Tachykinin-related peptides modulate odor perception and locomotor activity in Drosophila. Mol Cell Neurosci 31:399-406.

Woehler A, Ponimaskin EG (2009) G protein-mediated signaling: same receptor, multiple effectors. Curr Mol Pharmacol 2:237-248.

Xu TL, Duan B (2009) Calcium-permeable acid-sensing ion channel in nociceptive plasticity: a new target for pain control. Prog Neurobiol 87:171-180.

Yao Y, Choi J, Parker I (1995) Quantal puffs of intracellular $\mathrm{Ca}^{2+}$ evoked by inositol trisphosphate in Xenopus oocytes. J Physiol 482:533-553.

Zhang Q, Bengtsson M, Partridge C, Salehi A, Braun M, Cox R, Eliasson L, Johnson PR, Renström E, Schneider T, Berggren PO, Göpel S, Ashcroft FM, Rorsman P (2007) R-type $\mathrm{Ca}^{2+}$-channel-evoked CICR regulates glucose-induced somatostatin secretion. Nat Cell Biol 9:453-460.

Zucker RS (1996) Exocytosis: a molecular and physiological perspective. Neuron 17:1049-1055. 